\title{
PELATIHAN PERPAJAKAN UMKM BERDASARKAN PP 23 TAHUN 2018
}

\author{
Sunarti ${ }^{1}$ \\ Aris Eddy Sarwono ${ }^{2}$ \\ Fakultas Ekonomi, Universitas Slamet Riyadi \\ njarkasi@gmail.com
}

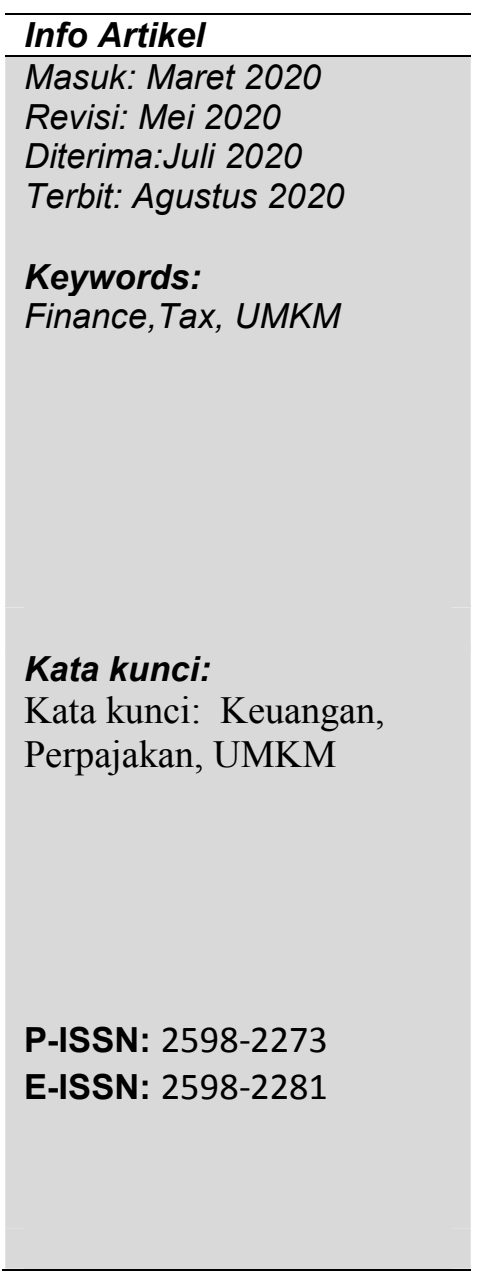

\begin{abstract}
Conventional and online MSME businesses have enormous potential in the country's economy. Various problems are faced by MSME actors, one of which is the problem regarding financial management and taxation, considering that MSME has the potential and excellent development prospects. Tax regulations change very dynamically, especially tax regulations for SMEs. Through this service program, the problem will be solved by providing assistance to the process of applying simple accounting and taxation to MSMEs.
\end{abstract}

\begin{abstract}
Abstrak
Bisnis UMKM konvensional maupun online memiliki potensi yang sangat besar dalam perekonomian negara. Berbagai permasalahan dihadapi oleh para pelaku UMKM salah satunya adalah permasalahan mengenai pengelolaan keuangan dan perpajakan mengingat UMKM ini memiliki potensi dan prospek pengembangan yang sangat baik. Peraturan perpajakan berubah sangat dinamis, khususnya peraturan pajak untuk UMKM. Melalui program pengabdian ini, permasalahan akan dipecahkan dengan melakukan pendampingan untuk proses penerapan akuntansi dan perpajakan sederhana pada UMKM.
\end{abstract}

\section{PENDAHULUAN}

Usaha Mikro Kecil Menengah tumbuh dan berkembang cukup pesat di Indonesia. Pesatnya perkembangan UMKM seiring dengan maraknya pengguna internet maupun sosial media. Pelaku bisnis online sebagian besar adalah usia produktif yang sangat akrab dengan social media. Perkembangan bisnis UMKM seharusnya diimbangi dengan pemahaman yang cukup mengenai regulasi 
perpajakan. Secara regulasi tidak ada perbedaan antara regulasi perpajakan usaha konvensional maupu E-Commerce karena status perpajakannnya hampir sama. Pajak penghasilan usaha bersumber dari penghasilan transaksi offline maupun online, setiap ada pernambahan emampuan ekonomi maka harus dikenakan pajak penghasilan. Sarana dn media merupakan hal pembeda system perpajakan online dengan konvensional.

Berdasarkan UU No. 36 Tahun 2008 pasal2 tentang pajak penghasilan, setiap orang pribadi, orang pribdi yang memiliki warisan yang belum dibagi, badan usaha dan BUT dikenakan pajak penghasilan. Menurut peraturan pemerintah No. 46 tahun 2013, PPH Final 1\% untuk UMKM atas penghasilan yang diterima kurang dari Rp 4,8 Milyar per tahun. Akan tetapi pada tahun 2018, terbit PP 23 Tahun 2018 mengenai penurunan tarif UMKM menjadi 0,5\% dari omset. Ketentuan tersebut untuk meningkatkan kepatuhan wajib pajak dan mengajak pelaku bisnis online untuk berkontribusi membayar pajak.

Pemerintah pada akhir tahun 2018 menerbitkan peraturan baru khusus untuk pelaku bisnis online melalui PMK 210/PMK.010/2018 yang semula akan diberlakukan efektif pada 1 April 2019. Akan tetapi ada banyak pertenyaan dan pertentangan dari masyarakat sehingga PMK 210 tidak jadi diberlakukan.

Pelaku usaha dari generasi milenial berperan sangat aktif dalam perkembangan UMKM konvensional maupun bisnis online. Jumlah mahasiswa yang memiliki usaha semakin meningkat dengan omset yang cukup besar. Pelaku usaha produktif ini diharapkan nantinya berpotensi dalam meningkatkan perekonomian negara, sehingga diharapkan mereka berkontribusi pada negara denga berperan aktif dan patuh membayar pajak. Sebagian besar pelaku usaha milenial belum melakukan pencatatan atau administrasi keuangan dengan cukup baik. Adanya pemahaman yang masih kurang atas hak dan kewajiban perpajakan serta stigma negative. terhadap petugas pajak. Peran akademisi sangat diperlukan untuk memberikan pemahaman yang cukup tifak hanya di ruang kelas tapi juga dalam bentuk sosialisasi, edukasi dan pelatihan.

\section{METODE PELAKSANAAN}


Identifikasi permasalahan mitra melaui pemetaan maslaah. UMKM diharapkan akan terus tumbuh dan berkembang. Keberlangsungan usaha dapat dilakukan dengan melakukan perencanaan strategis yang diimbangi dengan pemahaman yang memadai mengenai akuntansi sederhana dan kewajiban perpajakan untuk UMKM. Pada saat ini UMKM masih menerapkan system administrasi sederhana dan belum faham mengenai hak dan kewajiban perpajakan untuk UMKM. Transfer ilmu akan diterapkan apad UKM mitra sehingga diperoleh perbaikan sisstem administrasi dan perpajakan.

Solusi yang ditawarkan memberikan pengetahuna akuntans sederhana dan perpajakan bagi UMKM sesuai denga regulasi yang berlaku.merncang dan menerapkan program akuntansi dan perpajakan sederhana bagi UMKM.

\section{PEMBAHASAN}

Hasil yang dicapai selama pelatihan adalah peserta pelatihan ymembuat laporan keuangan usahanya dengan lebih sistematis tapi tidak rumit dan mudah untuk dilakukan. Metode pelaksanaanya dilaksanakan dengan datang langsung ke lokasi UKM dan memberikan pelatihan secara bertahap. Pemberi pelatihan berusaha memberikan pelatihan dengan menggunakan cara yang mudah dipahami dan dimengerti peserta pelatihan.

Peserta pelatihan merasa sangat terbantu dan sangat antusias mengikuti pelatihan karena pelatihan dibuat sederhana dan mudah. Peserta pelatihan diharapkan dapat membuat laporan sederhana dan mudah serta rapi, sehingga akan berguna untuk keberlanjutan usaha UMKM dan bisa sebagai dasara informasi yang cukup baik bagi pihak lain yang berkepentingan. Sistem akuntansi dan perpajakn sederhana ini diharapkan dapat diaplikasikan secara konsisten oleh pelaku usaha. Sistem sederhana ini memerlukan keseriusan dan konsistensi yang tinggi dari pelaku usaha dalam menerapkan sistem. Sistem yang sudah baik tidak akan berjalan dengan baik tanpa komitmen dari pelaku UMKM. Komitmen dalam implementasi secara konsisten akan mempermudah pelaku usaha dalam mencatat setiap transaksi usahanya.

Evaluasi akan dilaksanakan pada akhir kegiatan dan indikator yang akan 
digunakan dengan melihat aktivitas pelaku usaha dalam mengimplementasikan sistem akuntansi tersebut. Sistem sederhana ini diharapakan akan diaplikasikan dan dilaksanakan dengan baik oleh pelaku usaha. Pelaku usaha akan semakin mudah mudah dalam menyusun laporan keuangan usahanya.

Rencana setelah kegiatan selesai dilaksanakan yaitu akan ada pelatihan lainnya untuk seluruh UMKM yang masih belum memiliki sistem akuntansi dan perpajakan sederhana. Evaluasi akan dilakukan terhadap sistem, metode dan materi pelatihan. Evaluasi ini nantinya akan digunakan sebagai dasar rencana kegiatan pelatihan selanjutnya.

Pengembangan sistem akan terus dilakukan dan dengan metode yang lebih baik, sehingga akan mempermudah pelaku UMKM dalam memahami sistem akuntansi sederhana.pemahaman sistem akuntansi sederhana harus diberikan pada para pelaku usaha kecil untuk mempermudah penyususnan laporan keuangan sederhan. Laporan keuangan sederhana yang dapat dibuat pelaku usaha akan memberikan kemudahan dalam menyampaikan informasi keuangan usaha pada pihak-pihak terkait dan kewajiban perpajakan pelaku usaha akan dapat dilaksanakan dengan baik dan sesuai peraturan yang berlaku.

\section{PENUTUP}

Pelaku UKM diarahkan dan diberikan pelatihan sehingga mampu membuat dan meyusun laporan keuangan komersil dan fiscal dengan mudah dan praktis. Pencatatan transaksi dengan cara sederhana akan meringankan dan membuat mudah pencatatan yang semula dianggap rumit. Metode pelaksaan adalah dengan memberikan pemahaman dan pelatihan sistem akuntansi dan perpajakn sederhana. Peserta pelatihan sangat bersemengat mengikuti pelatihan meskipun pada awal pelatihan mereka sedikit mengalami kesulitan memahami beberapa istilah yang ada dalam akuntansi maupun perpajakan. Selain itu kendala lainnya adalah peserta belum terbiasa menggunakan sistem akuntansi dan perpajakan sebelumnya.

Pelaku usaha diharapkan konsisten dan tetap berkomitmen dalam pengaplikasian sistem sederahan ini. Evaluasi dan pengawasan akan dilakukan 
untuk terus membantu pelaku usaha dalam memahami dan mengaplikasian sistem akuntansi dan perpajakan ini

\section{DAFTAR PUSTAKA}

Hafsah, Jafar. 2004. Upaya Pengembangan Usaha Kecil dan Menenngah. Infokof Nomor 25 Tahun XX

Wexley, Kenneth N. 1991. Develoving and training humam resources in organization

Kuncoro, M. 2002. Analisi Spasial dan regional: studi glomerasi dank luster industi Indonesia. Yogyakarta

PP No. 23 Tahun 2013 